DOI https://doi.org/10.30525/978-9934-588-80-8-1.40

\title{
ОСОБЛИВОСТІ РОЗВИТКУ ПРОФЕСІЙНОЇ Я-КОНЦЕПЦІЇ В ПЕРІОД СТУДЕНТСТВА
}

\author{
Разумова О. Г. \\ аспірант кафедри психології \\ Донбаський державний педагогічний університет \\ м. Слов'янськ, Донещька область, Україна
}

Метою роботи $є$ представлення певних особливостей розвитку професійної Я-концепції студентів, які навчаються в педагогічних вищих навчальних закладах.

Студентський період в онтогенезі знаходиться між юністю та зрілістю. Цей етап можна назвати вирішальним в особистісному розвитку людини, оскільки його кінцевим результатом має бути формування внутрішньої психологічної цілісності поведінки й характеру, вміння визначити зв'язки внутрішніх змін і зовнішніх впливів, кооперація особистих інтересів із соціальними установками.

Головним психологічним протиріччям у студентському віці $\epsilon$ неузгодженість між прагненням до соціальної ідентифікації і потребою в особистому просторі. Потреба в особистому просторі, прагнення особисто приймати основоположні рішення в своєму житті, мати власну думку - все це характеризує вікові особливості особистості студента, яка розвивається. Ще Б.Г. Ананьєв вказував, що студентські роки - це період найбільш активного розвитку духовних та етичних якостей, становлення та стабілізації характеру, оволодіння якостями дорослого життя [1]. Рушійна сила періоду дорослішання - прагнення до особистісної ідентичності, або до «самосвідомості», близької до першої за смислом. Саме в цей період повною мірою формується уявлення про навколишню дійсність і своє місце в ній, формуються нові соціальні ролі, виникає потреба у прийнятті важливих рішень, які стосуються подальшої професійної діяльності.

Нинішнє покоління студентів суттєво відрізняється та має переваги перед своїми попередниками. Зокрема, це стосується форм навчання: сучасний студент може навчатися на денній, вечірній, заочній або дистанційній формах здобуття освіти. Значні переваги стосуються змісту освіти: студент може обирати вибіркові навчальні дисципліни, або факультативні заняття. Існує дуже багато гуртків та секцій, як безкоштовних, так і платних. Але основною перевагою $є$ відкритий 
доступ до різних джерел інформації, до сучасних інформаційних технологій, зокрема через мережу Інтернет. Для сучасного студента характерні якості, що відрізняють його від студентів минулих років. Так, сучасний студент легше адаптується до складних життєвих умов ринку праці, $є$ більш конкурентоспроможним, у нього розвинуті більша самостійність, вимогливість до викладача, але при цьому знизилась ерудованість, працелюбність, інтелігентність та вимогливість до себе.

Однією із головних умов професійної успішності фахівців, які працюють з людьми, є адекватне розуміння своєї особистості, власних достоїнств і недоліків, тобто підвищення рівня професійної самосвідомості. Складність, різносторонність і емоційна насиченість педагогічної діяльності вимагають від учителя адекватного розуміння себе як особистості i професіонала. У процесі самопізнання відбувається не лише усвідомлення тих або інших професійно важливих якостей, але й формується самооцінка, виникає певне емоційне ставлення до себе, почуття задоволеності або незадоволеності своєю діяльністю, емоційне переживання відповідності «Я-образу» ідеальним уявленням про себе як педагога. Лише усвідомивши себе в ролі вчителя, вихователя, особистість відкриває для себе можливості активного професійного саморозвитку, формування у себе професійно важливих якостей і вдосконалення педагогічної майстерності. Будучи інтегральною характеристикою особистості, професійна самосвідомість виступає важливою передумовою особистісно-професійного розвитку вчителя. У зв'язку 3 цим проблема професійної самосвідомості педагога інтенсивно досліджується в сучасній педагогіці, соціальній психології, психології особистості, педагогічній психології, психології професійної діяльності [2].

У психологічній літературі існує значна кількість праць, у яких розкривають проблему формування та розвитку професійної Я-концепції у представників різних професій. Так, зокрема, професійне становлення особистості вчителя розглядали І.Д. Бех, Г.А. Бордовський, І.Ф. Ісаєв, Є.А.Гришін, С.Д. Максименко, А.В. Мудрик, Д.Ф. Ніколенко, В.О. Сластьонін, В.Д. Шадриков та ін.

Особливостями розвитку і становлення професійної Я-концепції та самосвідомості лікарів та медичних сестер займались такі вчені, як А.Г. Васюк, О.В. Денисова, М.І. Жукова, Т.В. Румянцева, Н.В. Яковлєва, К.Ю. Ушакова.

Аналіз iï особливостей, специфіки професіоналізму практичних психологів представлений у працях Г.С. Абрамової, О.С. Анісімова, О.Г. Асмолова, М.Р. Бітянової, Б.С. Братуся, В.М. Дружиніна, І.В. Дубровіної та ін. 
Особливості професійного самовдосконалення та розвитку майбутніх інженерів вивчав А.О. Ігнатюк, майбутніх офіцерів та прикордонників - О.В. Діденко, О.В. Стельмах.

Над проблемою формування педагогічного мислення працювали

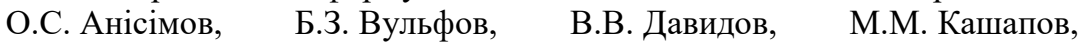
Ю.М. Кулюткін.

Результати численних досліджень переконливо доводять, що в процесі отримання професії у майбутніх педагогів відбуваються якісні зміни всіх структурних компонентів професійної Я-концепції. Передусім це зміна уявлення про себе як про професіонала на теоретичному рівні, оскільки більшу частину навчального процесу займає теорія. У зв'язку з цим студенти зіштовхуються 3 проблемою застосування отриманих знань, умінь та навичок на практиці, що тягне за собою невпевненість у собі як у спеціалісті і, як наслідок, ослаблення професійного «Я»-образу.

У психологічних і педагогічних дослідженнях категорія професійної Я-концепції вчителя описується за допомогою різних термінів: педагогічна рефлексія, ідентичність, самопізнання, самоаналіз, самокритичність, професійна відповідальність, образ Я, самооцінка, Я-концепція тощо. Більшість науковців наголошує на важливій ролі розвитку професійної Я-концепції вчителя як невід'ємної складової його професіоналізму i компетентності, педагогічної культури, творчості і майстерності.

Я-концепція студента - майбутнього педагога - являє собою особливий конструкт професійної особистості, який $є$ результатом активного осмислення спеціалістом власних професійно значущих властивостей. Особливого значення професійна Я-концепція набуває у зв'язку з тим, що вона відображає процеси активного самопізнання, саморегуляції й самовдосконалення у професійній діяльності.

Професійна концепція складається 3 трьох основних компонентів: когнітивного, афективного, конативного (поведінкового). Під професійною Я-концепцією педагога розуміється усвідомлення себе в кожному з трьох основних аспектах професійної праці: в діяльності, у спілкуванні, а також у системі самої особистості педагога.

На думку деяких вчених, психологічною особливістю студентського віку є спрямованість у майбутне, попереднє самовизначення, побудова життєвих планів. Одним із найважливіших новоутворень віку вважається формування Я-концепції і особистісної ідентичності. Проходячи кризу ідентичності, індивід усвідомлюе тотожність самому собі. Е. Еріксон вважав, що криза ідентичності включає в себе низку протистоянь: часова перспектива або розмите відчуття часу; упевненість у собі або 154 
сором'язливість; учнівство або параліч трудової діяльності; сексуальна поляризація або бісексуальна орієнтація; стосунки лідер/переслідувач або невизначеність авторитету; ідеологічна переконаність або сплутаність системи цінностей [3].

Первинна інформація про власну професію, певні очікування i вподобання створюють своєрідний ідеальний образ обраної професії свій у кожного студента. Першопочатковий узагальнений образ типового професіонала змінюється в ході навчання й розвитку студентів. Рефлексивне співвіднесення нового образу професії 3 власним образом Я вносить корективи у професійну самосвідомість $\mathrm{i}$ професійну Я-концепцію. Когнітивна складова включає також професійні переконання i знання. Емоційно-смислова складова професійної Я-концепції тих, хто навчається, визначається емоційнопозитивним фоном, на якому відбувалося отримання первинної i подальшої інформації про майбутню професію, позитивним сприйняттям себе як суб'єкта професійної діяльності, позитивним прийняттям своєї майбутньої належності до цього професійного співтовариства, успішним засвоєнням відповідних знань і способів діяльності, пізнавальних стратегій. Поведінкова складова Я-концепції студентів дозволяє реалізовувати, перевіряти й коригувати свій професійний образ Я в навчальній діяльності і спілкуванні. Вирішуючи проблемні ситуації в навчально-професійній діяльності, студент не лише здобуває адекватні уявлення про майбутню професію і свої можливості, але й активно їх розвиває. Поведінкова складова виражається також в реалізації намірів добросовісно засвоювати навчальні предмети, удосконалюватися в обраному напрямку i в подальшому працювати в обраній професії. Мотиваційно-ціннісна складова професійної Я-концепції студентів виражається в усвідомленні своїх потреб, можливостей, професійних інтересів i цінностей, у створенні позитивних образів і перспектив професійного майбутнього, в мотиваційній готовності до розвитку своєї особистості, до входження в професійне співтовариство й реалізації себе в обраній професії. У рамках професійної Я-концепції формується уявлення людини про професійне майбутне, ставляться конкретні цілі. Досягнення цих цілей здійснюється через активність, яка спирається на рефлексивну оцінку людиною ситуацій, своєї діяльності і стосунків, потребує самоконтролю.

Адекватно сформована професійна Я-концепція студента є основою професійного й творчого розвитку спеціаліста, тому у системі вищої професійної освіти необхідно приділяти особливу увагу формуванню рефлексивних стратегій пізнавальної діяльності тих, хто навчається. 


\title{
Література:
}

1. Ананьев Б.Г. Психологическая структура человека как субъекта / Б.Г. Ананьев // Человек и общество / под ред. Б.Г. Ананьева. - Л., 1967. Том 2. C. 235-249.

2. Галузяк В.М. Педагогічна підтримка розвитку особистісної зрілості майбутніх учителів / В.М. Галузяк // Особистісно-професійний розвиток майбутнього вчителя: монографія / Акімова О.В., Галузяк В.М. [та ін.] - Вінниця: ТОВ «Нілан ЛТД», 2014. - С. 40-80.

3. Эриксон, Э. Жизненный цикл: эпигенез идентичности / Э. Эриксон // Теории личности в западно-европейской и американской психологии: хрестоматия по психологии личности. Самара: Бахрах, 1996. $-458 \mathrm{c}$.

DOI https://doi.org/10.30525/978-9934-588-80-8-1.41

\section{ШКІЛЬНА ЛОГОПСИХОДІАГНОСТИКА: ТЕОРЕТИКО-МЕТОДОЛОГІЧНІ АСПЕКТИ}

\author{
Рібцун Ю. В.
}

кандидат педагогічних наук, старший науковий співробітник, старший науковий співробітник відділу логопедії

Інститут спеціальної педагогіки і психологї імені Миколи Ярмаченка Начіональної академії педагогічних наук України м. Київ, Україна

Трансформація сучасної освіти, зокрема спеціальної, обумовлена впровадженням Концепції Нової української школи, потребує нагального вирішення ряду актуальних питань, серед яких чи не найважливішим $\epsilon$ питання психолого-педагогічної допомоги особам, котрі мають мовленнєві порушення. Загальні стратегії психологопедагогічної допомоги здобувачам початкової освіти 3 особливими мовленнєвими потребами здійснюється в трьох взаємопов'язаних напрямах: 1) психодіагностика; 2) психокорекція; 3) психологічне консультування.

Психодіагностика - напрям практичної психології, в рамках якого вивчаються принципи, засоби побудови, методи визначення, оцінки та аналізу психологічних особливостей дитячої особистості, застосування діагностичних процедур 3 метою визначення кількісних і якісних показників окремих психологічних феноменів (Ю. Алєксєєва, 